\title{
Liberal Citizenship Is Duty-Free
}

\author{
Christian Joppke
}

Maurizio Ferrera has produced an admirably detailed and savvy catalogue of suggestions to 'add stuff' to European Union citizenship, particularly on its social rights dimension. The idea is that more deliverables, particularly for the vast majority of Europeans who do not take advantage of the right of free movement that remains the beating heart of EU citizenship, will increase the cohesive and integrative powers of the European citizenship, and allow to attach some 'soft' duties to it that in its current form are entirely missing. The question whether EU citizenship 'should' be duty-free is only tangentially raised, and it is presumed rather than discussed that the only reasonable answer could be negative.

While the spirit of this proposal is 'incremental' and pragmatic, I would like to question some larger presumptions that go into it. The first and central is that duties are a necessary component of citizenship. However, tax paying and army service, which are mentioned by Ferrera as 'novel duties' attached to the rise of national citizenship, and apparently considered as model duties for a strengthened EU citizenship also, are no specific citizen duties. All legal residents are required to pay taxes; and most armies today are professional and thus facultative (and some armies, like the American, following the Imperial Roman model, also recruit non-citizens). As already Hans Kelsen observed, even 'allegiance', that quintessential citizen duty, is not a legal duty but merely a 'political and moral' exigency: 'There is no special legal obligation covered by the term allegiance. Legally, allegiance means no more than the general obligation of obeying the legal order, an obligation that aliens also have'. ${ }^{1}$

Kelsen wrote this at a time when 'treason' was still a crime that only citizens could commit; its functional equivalent today, 'sedition', which is the legally enforceable opposite of allegiance, is a crime that non-citizens also can be charged for. ${ }^{2}$ A non-starter at the national level already, where - as

1 Kelsen, H. (1949), General Theory of Law and State. Cambridge, Mass.:

Harvard University Press, p. 235.

2 See Fletcher, G. (1993), Loyalty: An Essay on the Morality of Relationships.

New York: Oxford University Press, chapter 3. 
Dimitry Kochenov put it - citizenship has undergone a process of 'liberal de-dutification', it is obvious that a 'dutified' EU citizenship would be extra-anachronistic.

This leads me to question a second presumption of Ferrera's proposal, which is that national citizenship provides a model for EU citizenship. If anything, one might argue, in reverse order, that EU citizenship provides a model (and guarantor) of a 'lightened' citizenship that is observable at the state level already. ${ }^{4}$ For Ferrera, the direction is for EU citizenship to move up to the national model. This entails certain questionable idealisations, for instance, of national citizenship to feed 'affectual and normative loyalty visà-vis state authorities and their binding decisions' (Ferrera). When was that, and where, one must ask. From the ground up, states are better conceived as 'protection rackets', so that an 'affectual and normative' attitude to that sort of thing appears delusional, at best. Undeniably, in the nationalist past, citizenship was a reason for people to spill their blood and that of others, and it was a ground to be duped by 'state authorities' (who is that, one must continue asking). It isn't, and shouldn't be, today. Add to this the element that the EU is no ordinary state. If the equivalent of 'state authorities' in Brussels, which is the European Commission, decides to relicense Monsanto's glyphosate, a controversial weed killer that is strongly suspected by the World Health Organisation to be carcinogenic to humans, in this decision presumably not uninfluenced by this multinational's formidably resourceful, statedwarfing lobby, ${ }^{6}$ there shouldn't be a EU citizenship tranquilizer around to let that pass as 'binding decision'. Perhaps it would be a category mistake to deploy the citizenship concept in the first place. The EU is a regulatory regime, not a protection racket, so that 'citizenship', which has grown out of a protection logic, providing a flowery 'allegiance' and 'loyalty' coating to the elementary state function of providing security, is the wrong concept to

Kochenov, D. (2014), 'EU Citizenship Without Duties', European Law Journal 20 (4): 482-498.

4 See Joppke, C. (2010), 'The Inevitable Lightening of Citizenship', European Journal of Sociology 51 (1): 9-32.

5 Tilly, C. (1985), 'War Making and State Making as Organized Crime', in P. Evans et al. (eds.), Bringing the State Back In, 169-187. New York: Cambridge University Press.

6 'European Commission Plans to Relicense Controversial Weedkiller', The Guardian, 24 February 2016, available at https://www.theguardian.com/ environment/2016/feb/24/weedkiller-glyphosate-controversial-european-commission-plans-relicense. One must concede, however, that the European Commission's stubborn support for the multinational is backed by some large member states, including Germany and France. 
begin with. Citizens and others have every reason to be suspicious of a notionally technocratic but still humanly fallible European Commission that is only indirectly, if at all, liable to democratic constraints. Karl Marx would be posthumously redeemed if 'citizenship' were available to feed 'affectual and normative loyalty' to that elite.

There is a third problematic presumption in Ferrera's proposal to 'add stuff' and to 'dutify' EU citizenship, which is the idea that 'moving' - incidentally, by a tiny group that does not even cross the five per cent mark of the EU population - causes harm that 'stayers' should be indemnified for. As Ferrera writes, EU citizenship 'has empowered ... mobile citizens, at the (perceived) expenses of large majorities of nonmobile citizens'. Ferrera cautiously talks about 'perception' here but then gives credence to it by proposing to compensate for the 'negative externalities' of free movers and to 'empower' the stayers. This would give legal dignity to the ur-trope of European populists, that of migrants as perpetrators and of natives are victims. More fundamentally still, it buys into the populists' hideous re-labelling of mobile EU citizens as 'immigrants'. It is a fact that the fiscal effects of post-Enlargement migration into the UK, mainly from Poland, which has been the single-biggest theme of the Brexit campaign, have been positive. But then it would reward the British state twice over if taxpayers of other EU states were to pick up the bill of the region-specific infrastructural impasses (schooling, health care, transport, etc.) that are inevitably caused by this migration. In short, any scheme that gives legal dignity to slicing the European citizenry into two unequal halves, movers and stayers, with the perverse and absolutely anti-European connotation of moving as harmful and staying as virtuous (at least, as something to be rewarded for), is dangerous, because it confirms the demonology of European populists.

This is not to deny that the binary of moving v. staying maps closely into that of openness v. closure, which is the central new cleavage of societies undergoing globalisation, being layered over the classic left-right cleavage that has structured Western politics for over 200 years. However, if the old cleavage was reconciled by the welfare state and its social citizenship, doubts are allowed that these compromise structures can be simply applied to a new situation in which globally mobile capital has greatly diminished the fiscal capacity of the state and its judicial authority over the economy. The European citizenship, in contrast to traditional citizenship that eulogises the value of staying and closure, has moving and openness written on its forehead. No compensatory EU funds for stayers or tangible benefits for tourists, patients, students, consumers, via a 'EU Social Card', etc., as proposed with alacrity and a great sense of practicality by Ferrera, will ever warm up the stayers to 
'Europe'. Peter Spiro nicely describes the novelty of the day that a Londoner opposing Brexit will feel closer to a New Yorker opposing Trump than to their notional fellow-citizens in the province voting for Brexit or Trump. ${ }^{7}$ Or as David Goodhart commented on Brexit opponents' sense of waking up 'in a different country' on the morning of June 24,2016 , this is exactly how Brexit proponents had felt before the fateful referendum. ${ }^{8}$ Both camps quite literally inhabit different spaces, from the mental to the physical, and are tied up in incompatible loyalty structures. 'Citizenship' has become an obsolete clip to tie them together. The cohesion and bottom-up support that the European project needs to survive, and to move on, is unlikely to stem from cosmetic corrections to a citizenship that cannot but be partisan in the openness v. closure rift. More urgent would be to end the intolerable situation that not just populist movements but entire member states have decisively thrown themselves on the 'closure' end of the spectrum, opposing Europe from within it, by building 'illiberal democracies' that openly repudiate the common values upon which the EU also legally rests.

Finally, if I understood Ferrera correctly, he defends his proposal as one that would sharpen the distinction between privileged EU citizens and less privileged third-state nationals, or 'immigrants' proper, because only EU citizens but not settled immigrants are meant to benefit from the proposed social policy measures. This strikes me as retrograde (and against the territorial logic of providing welfare). The thinning distinction between citizens and legal permanent residents is a side-effect of a larger liberalisation of citizenship in Western states and of the 'civilising' of nationhood that undergirds the latter. This is a hard-won achievement, not a liability. For the opposite tribal model of a citizen elite tightly sealed from second-class immigrants, consult the Gulf States. It would be ironic if the European Union, which has been created to tame nationalist exclusiveness, were now to mimic it.

These somewhat grand-scheming objections, some perhaps more plausible than others, are raised for the sake of debate; they are not meant to diminish Ferrera's powerful and deeply knowledgeable proposal. We share the same vision of strengthening the European citizenship. At heart, however, I would guard against the notion that citizenship should be duty-full. Liberal citizenship is duty-free, in a legal (not moral!) sense, and EU citizenship is even more so. A citizenship that imposed hard legal duties was the

7 Spiro, P.J. (2017), Citizenship After Trump Center for Migration Studies, available at http://cmsny.org/publications/spiro-citizenship-after-trump/.

8 Goodhart, D. (2017), The Road to Somewhere. London: Hurst. 
'citizenship' of communist states, today also that of Islamic states, which arrogate to themselves a strong formatting of the preferences and beliefs of their members. This is not a model to follow, because it impairs liberty.

Open Access This chapter is licensed under the terms of the Creative Commons Attribution 4.0 International License (http://creativecommons.org/licenses/by/4.0/), which permits use, sharing, adaptation, distribution and reproduction in any medium or format, as long as you give appropriate credit to the original author(s) and the source, provide a link to the Creative Commons license and indicate if changes were made.

The images or other third party material in this chapter are included in the chapter's Creative Commons license, unless indicated otherwise in a credit line to the material. If material is not included in the chapter's Creative Commons license and your intended use is not permitted by statutory regulation or exceeds the permitted use, you will need to obtain permission directly from the copyright holder.

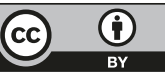

